\title{
Effect of Bulbils Position on Leaf Branches to Plant Growth Responses and Corms Quality of Amorphophallus muelleri Blume
}

\author{
Retno Mastuti*, Nunung Harijati, Estri Laras Arumingtyas, Wahyu Widoretno
}

Department of Biology, Faculty of Mathematics and Natural Sciences, University of Brawijaya, Malang, Indonesia

Abstract

Bulbil (corm leaf) is one material source of vegetative propagation in Amorphophallus muelleri Blume. Based on the position in branches there are two types of bulbil, middle and edge bulbils, which are different in shape and size. It has been reported that bulbil size affected not only the growth response of seedlings and plants but also the quality of the produced corms. Therefore, the objectives of this experiment were to study the effect of bulbils origin on $A$. muelleri Blume (Porang) growth and the quality of harvested corms. The quality of corms was assessed based on glucomannan and $(\mathrm{CaOx})$ content. Bulbils from the middle and edge of branches were grown in polybag $(\phi 5 \mathrm{~cm})$ containing compost:fertilizer (1:1) mixed media under $40 \%$ shade. Each bulbil origin was repeated 8 times. The results showed that growth responses of plant from middle bulbil were significantly better than that from edge bulbil. However, at the harvesting time, the weight and diameter of corms derived from both types of bulbils were not significantly different. The glucomannan and calcium oxalate $(\mathrm{CaOx})$ content of harvested corms grown from middle bulbil tends to be higher than that from edge bulbil.

Keywords: branching, calcium oxalate ( $\mathrm{CaOx})$, germination, glucomannan, Porang.

\section{INTRODUCTION}

Porang, Amorphophallus muelleri Blume ( $A$. muelleri) is one members of the Araceae that produce corms which is actually an underground stem. It is native to Indonesia [1] especially in teak forests in East Java and in undisturbed areas such as riversides and bamboo forests in Central and West Java [2]. It can grow in lowlands areas up to $1000 \mathrm{~m}$ above sea level, with temperatures between $25-35^{\circ} \mathrm{C}$ and rainfall between $300-500$ $\mathrm{mm}$ per month during the period of growth [3]. The plant will grow better under shade. Environment with shade of $50-60 \%$ has high production of corms [1]. Amorphophallus muelleri has unique, highly dissected, umbrella-shaped leaf blade which is supported by pesudo-stem or petiole $[4,5]$. The dissected leaf blade has some branches (leaflets) which are supported by petiolule.

Amorphophallus muelleri can be regenerated through generative and vegetative propagation $[1,3]$. Bulbils or corms leaf are organ source of vegetative propagation of $A$. muelleri besides corms. The bulbils of $A$. muelleri are classified as epiphyllar bulbil because they were produced on the surface of branching points of the leaf [4]. Based on the position on leaf branches there are

\footnotetext{
* Correspondence address:

Retno Mastuti

Email : mastuti7@ub.ac.id

Address : Dept. Biology, Faculty of Mathematics and Natural Sciences, University of Brawijaya, Veteran Malang, Malang 65145.
}

two types of bulbils: middle and edge bulbils which are produced on leaf [6] and leaflet branching points, respectively. Spatial distribution of bulbils on leaf contributed to variations in shape, weight and size the bulbils [3]. Middle bulbils have brown color and round shape while edge bulbils have oval shape and smaller than the former. Edge bulbils on the primary leaflet are bigger than that on secondary and tertiary leaflet. Propagation of $A$. muelleri from bulbils is more promising than from seeds. Plants derived from bulbils grew faster than those derived from seeds. At the third stage of growth period plants derived from bulbil were higher $( \pm 180 \mathrm{~cm})$ than those derived from seeds $( \pm 140 \mathrm{~cm}$ ) [7].

Considerable degree of seed heterogeneity in size, weight and quality has been widely reported $[8,9,10]$. The effects of bulbil size on the plant growth and corms quality of $A$. muelleri derived from different bulbil size have also been reported $[7,11,12]$. Different sizes of bulbil showed no difference in the ability to grow but it has effect on plant growth responses [11]. Large bulbils generate higher plants than small bulbils but the diameter of stem and leaves and the number of shoots were not significantly different [12]. It has also been reported that bulbil size determined the amount of the stage of vegetative growth and dormancy [7]. Different sizes of bulbil that were grown in medium containing various doses of lime produced corms with different level of glucomannan content [11]. 
Position-dependent effects have been widely studied on seed or fruit $[13,14,15]$. The position of a seed or fruit on plant can affect its morphology, mass and dormancy/germination $[16,17,18]$. However, regarding to corms studies still focused on the placement position on propagation media or planting area [19] rather than the corms position on the maternal plant. The duration of Liatris daughter corms' growth to maturity and their growth rate vary with their position on the mother corm [20].

Currently market demand for the A. muelleri chip corms is quite high. Amorphophallus muelleri corms have been widely used as raw materials in food, cosmetics and pharmaceutical industry because they contained valuable source of glucomannan, a soluble, non-cellulosic polysaccharide [21]. Chips derived from A. muelleri corms are highly exported to Japan, Hongkong and China and other countries. Therefore, today in Indonesia $A$. muelleri has been cultivated in several methods of propagation to produce high quality of corms to meet the increasing market demand.

Considering some previous reports which showed that bulbil size affects the growth response, therefore the spatial distribution of $A$. muelleri bulbil on leaf and leaflet branching is necessary to be examined both in physiological and morphological responses. Therefore, the objectives of the present study were to examine plant growth response and corms quality grown from middle and edge bulbils produced on leaf branches of $A$. muelleri.

\section{MATERIALS AND METHODS \\ Bulbil Germination}

Middle and edge bulbils derived from the second growth period of plants were obtained from Oro-oro Waru Village, Saradan, Madiun District, in East Java, Indonesia. Eight bulbils of each type were germinated in plastic bags $(\phi=5$ $\mathrm{cm})$ containing $\pm 500 \mathrm{~g}$ fertilizer:compost (1:1) mixed media. The bulbils were planted $5 \mathrm{~cm}$ depth in the media and the plastic bag then placed in the experiment field of Biology Department, University of Brawijaya under $40 \%$ shading. After bulbil-derived seedling has reached a height of $\pm 20 \mathrm{~cm}$ then it was grown in larger polybag $(\phi=40 \mathrm{~cm})$ containing @ $5 \mathrm{~kg}$ soil media. Plants were watered to about field capacity twice a week.

Plant Growth and Corms Harvesting

The measurement growths responses were started at three months after the coleoptile sheath merged on the soil surface, once a week for 10 weeks. The parameters of growth responses measured were plant height, stem girth and canopy width. Plant height was measured from petiole base on the soil surface to the top of leaf canopy. To measure canopy width, firstly the two range poles of the extreme edges of the canopy were marked. Subsequently, the distance between the two poles was measured with a measuring tape and recorded as the canopy width. The corms were harvested at \pm 90 days after planting, and prepared for glucomannan and $\mathrm{CaOx}$ analysis.

\section{Extraction and Analysis of Glucomannan Con- tent of Fresh Harvested Corms}

Fresh harvested corms were rinsed and the skin was peeled. Total $6 \mathrm{~g}$ of the rinsed flesh corms were mashed using blender to form pasty. Subsequently, glucomannan extraction and analysis were conducted based on the method of [22] with modification. Pasty of corm was put into beaker glass containing $200 \mathrm{~mL}$ of $\mathrm{AlSO}_{4} 0.3 \%$ and then placed in an incubator at $55^{\circ} \mathrm{C}$ for $15 \mathrm{~min}$ while stirred gently to maximize the process of glucomannan extraction. The extract yield was filtered with cotton cloth, diluted until the final volume reached $600 \mathrm{~mL}$ and then centrifuged at $1500 \mathrm{~g}$ for $15 \mathrm{~min}$. Supernatant was added by isopropyl alcohol with ratio 1:1. The white precipitate formed was glucomannan. The precipitate glucomannan was oven-dried at $45^{\circ} \mathrm{C}$ overnight or until dry to obtain glucomannan yield. The weight of dry glucomannan relative to the weight of dried corm used for calculating glucomanan content. The weight of dried corms were obtained from $6 \mathrm{~g}$ of flesh corms that was rinsed, chopped and dried by oven at $45^{\circ} \mathrm{C}$ overnight or until dry. Dried glucomannan sample was weighed and glucomannan content per DW sample was calculated as: (precipitate DW/corms sample DW) x 100\%.

\section{Extraction and Analysis of Calcium Oxalate (CaOx) of Fresh Harvested Corms}

Extraction and determination of $\mathrm{CaOx}$ content of $A$. muelleri corms were conducted by the method of Imouha and Kalu [23] with modification. Determination of $\mathrm{CaOx}$ consisted of three phases: digestion, oxalate precipitation and titration of permanganate. Corms were rinsed and then approximately $1 / 4$ parts of them was grated. The digestion phase was initiated by dissolving 10 g grated corms into $190 \mathrm{~mL}$ aquadest and then added by $10 \mathrm{~mL}$ of $\mathrm{HCl} 6 \mathrm{~N}$. The suspension was heated at $100^{\circ} \mathrm{C}$ for $1 \mathrm{~h}$ then allowed to cool. 


\section{A. muelleri Blume (Mastuti et al)}

Aquadest was added into the suspension until reached volume $250 \mathrm{~mL}$ and it was filtered by fine cotton cloth. The second phase was initiated by adding six drops of methyl red into filtrate yield. The $\mathrm{pH}$ was adjusted by adding some drops of $\mathrm{NH}_{4} \mathrm{OH}$ until achieved $\mathrm{pH}$ 4-4.5. Subsequently filtrate was heated until $90^{\circ} \mathrm{C}$ and then allowed to cool. Filtrate was filtered by whattman no. 1 to eliminate Fe. Filtrate was heated at $90{ }^{\circ} \mathrm{C}$, added by $10 \mathrm{~mL}$ of $\mathrm{CaCl}_{2} 5 \%$ and homogenized by magnetic stirrer. Finally, the filtrate was centrifuged at $2500 \mathrm{rpm}$ for $10 \mathrm{~min}$. At the last phase pellet derived from previous centrifugation was put into $10 \mathrm{~mL}$ of $\mathrm{H}_{2} \mathrm{SO}_{4} \quad 20 \%$. After added with aquadest until reached the volume of $100 \mathrm{~mL}$ the solution was heated until almost boiled. Subsequently, titration of this solution was conducted by standardized $\mathrm{KMnO}_{4} 0.1 \mathrm{~N}$ until produced pink color for $1 \mathrm{~min}$. The content of $\mathrm{CaOx}(\mathrm{g} / \mathrm{FW}$ corms/tubers) was calculated with Eq. 1.

$\mathrm{CaOx}(\mathrm{g})=\frac{\mathrm{V}_{\mathrm{KMnO4}} \times \mathrm{M}_{\mathrm{KMnO4}} \times{ } \times \text { x ME } \times \text { DF } \times 100}{m_{f} \times 1000}$

\section{Description:}

VKM $_{n} \mathrm{O}_{4}$ is volume $\mathrm{KMnO}_{4}(\mathrm{~mL})$, $\mathrm{M} \mathrm{KM}_{\mathrm{n}} \mathrm{O}_{4}$ is molarity $\mathrm{KMnO}_{4}$,

$\mathrm{ME}$ is molar equivalent of $\mathrm{KMnO}_{4}$ in oxalic,

$\mathrm{DF}$ is dilution factor, and

$m_{f}$ is mass of fresh corms

\section{Statistical analysis}

Data were subjected to analysis of variance (ANOVA) and means were compared by Tukey test $\alpha 0.05$ using the SPSS ver. 17.

\section{RESULT AND DISCUSSION}

Growth Responses of Plants Derived From Different Types of Bulbils

Middle bulbils have bigger size than edge bulbils (Fig. 1). Both types of bulbils showed significantly different vegetative growth responses. Plants derived from middle bulbils grew faster than that from edge bulbils (Fig. 2A). Plant height derived from different bulbil types showed significantly differentt from the first week until the last week of observation (Fig. 2B). From week to week the plants derived from middle bulbils were taller than those derived from edge bulbils. At the last week observation the plant height derived from middle bulbils reached $60.0 \pm 4.7 \mathrm{~cm}$ while those from edge bulbils reached only 47.5 $\pm 4.1 \mathrm{~cm}$. But until the last week the average height of plants derived from each middle and edge bulbils was not significantly different from the first week observation.

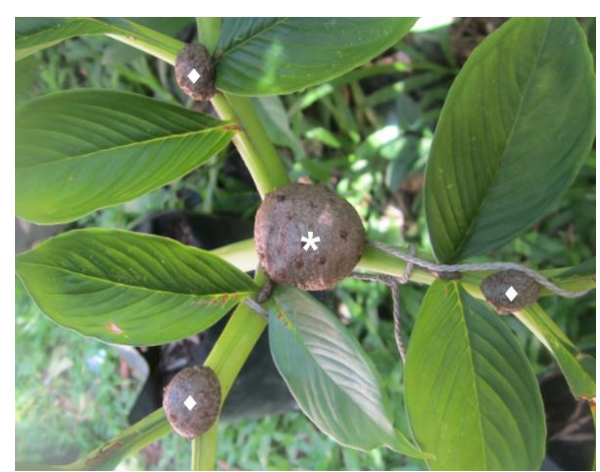

Figure 1. Bulbil. (cormes leaf) of $A$. muelleri on leaf branching. * middle bulbil, edge bulbil
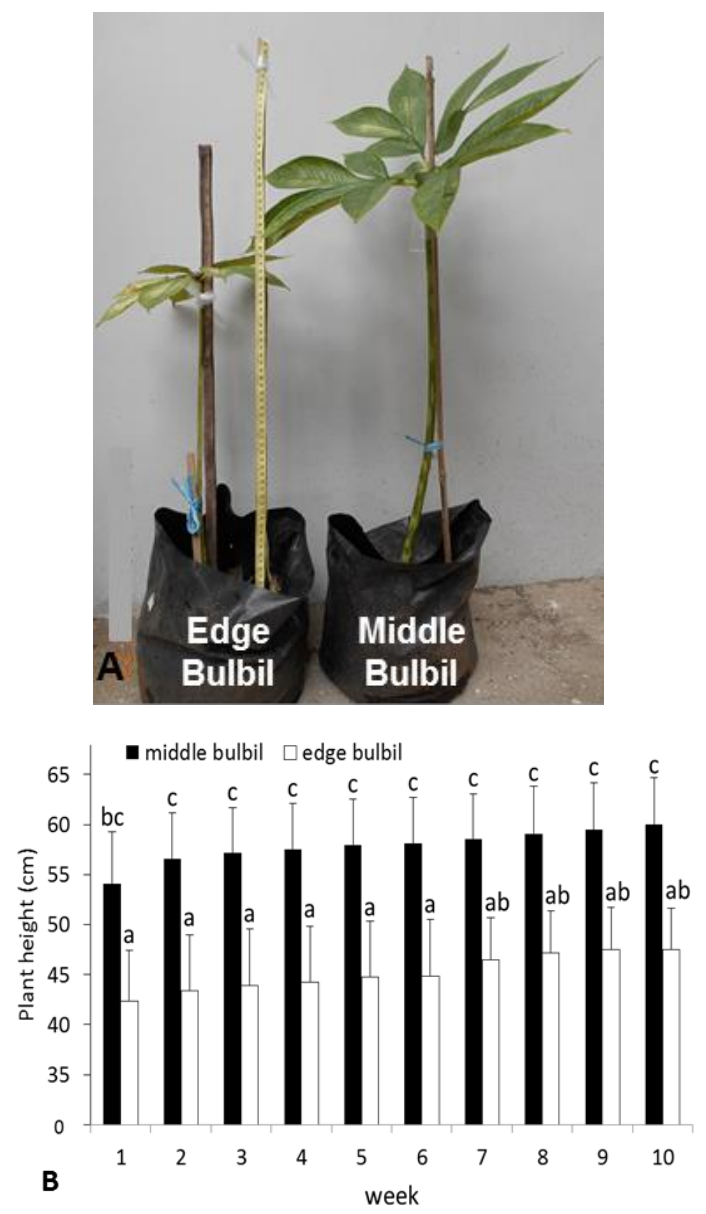

Figure 2. Plant height of $A$. muelleri derived from middle and edge bulbils. (a) A. muelleri plants 10 weeks after seedling germination and (b) Plant height at each week observations. Different letters following bars indicate significant differences at the $\alpha=0.05$ of Anova test. Means \pm SD $(n=8)$.

Stems girth of plants grown from middle bulbils $(14 \pm 1.39 \mathrm{~cm}$ ) were also significantly greater than those grown from edge bulbils $(10 \pm 0.60$ $\mathrm{cm}$ ) (Fig. 3A). Canopy width from both types of bulbils was also significantly different. It derived from middle bulbils had longer diameters than that derived from edge bulbils (Fig. 3B). The de- 
velopment of storage organ grown from middle and edge bulbils which was represented by weight and diameter of harvested corms were not significantly different. The weight of harvested corms of plant grown from middle and edge bulbils reached $73.3 \pm 37 \mathrm{~g}$ and $49.6 \pm 13.8 \mathrm{~g}$, respectively. Diameter of harvested corms of plant grown from middle and edge bulbils reached $54.4 \pm 10.2 \mathrm{~mm}$ and $48.2 \pm 4.5 \mathrm{~mm}$, respectively (Fig. 4A).

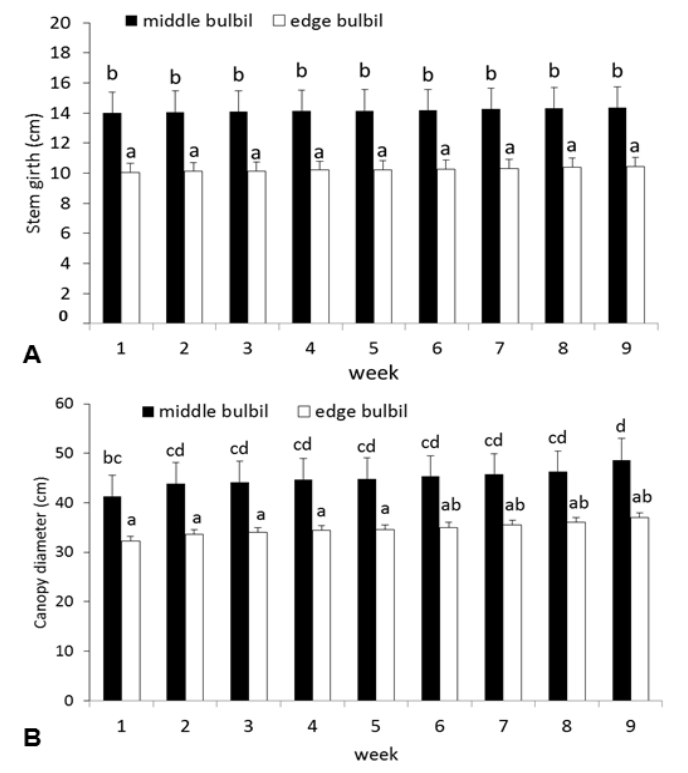

Figure 3. Stem girth and canopy diameter of $A$. muelleri plants. (a) Stem girth and (b) Canopy width. Different letters following bars indicate significant differences at $\alpha=0.05$ of Anova test. Means \pm $\operatorname{SD}(n=8)$.

Bulbil of $A$. muelleri is a small cormes produced on leaf branch. Bulbil is a sink containing storage resources translocated from photosynthetic organs. The size of bulbil indicated the amount of storage resources possessed. In this study the middle bulbils which have bigger size showed better primary and secondary growth responses than edge bulbils based on plant height, stem girth and canopy width. Middle bulbils of $A$. muelleri is apparently to contain greater numbers of photosynthate as food reserves so the process of photosynthesis occurs earlier and the vegetative organs formed faster than edge bulbils. Sumarwoto and Maryana [12] have reported that bigger size of $A$. muelleri bulbil produce higher plant than smaller ones. The same results were shown in other species. Bulb size influenced plant growth and development of Hyacin and Lily [24]. Corms size affected the performance of Gladiolus grandiflorus $[25,26]$ as well as stigma and corm yield of saffron (Crocus sativus L.) [19].

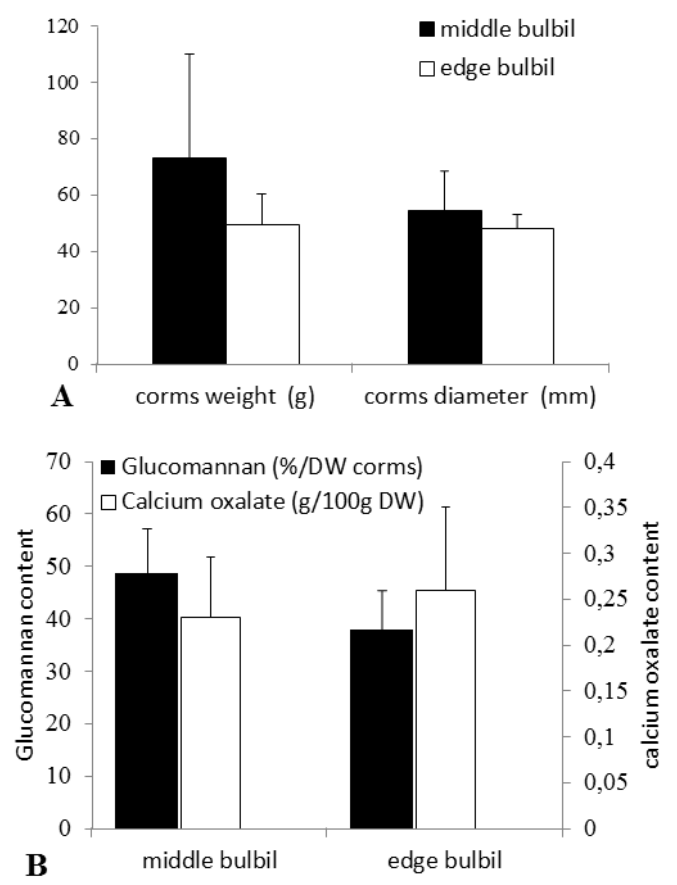

Figure 4. Quality of $A$. muelleri harvested corms planting from different types of bulbils at 90 days after planting: (a) Weight and diameter of harvested cormes and (b) Glucomannan and Calcium oxalate content. Means $\pm S D(n=8)$.

Environment is predominant factor which determine size variation of seed produced as a source of generative reproduction [8]. Withinplant variation can be determined by fruit position and seed position within a fruit or inflorescences. Bulbils of $A$. muelleri are vegetative reproduction organ which sized vary as a result of their position on the leaf branch of maternal plants. This maternal position effect of $A$. muelleri bulbils occur in a structurally ordered manner. Bulbils on more periphery branch have smaller size. Within-plant variation arising from position effects is inherited [8]. Effect of seed position resulted in variations in size is always present in every generation. This shows that the inherited character which is more affected by position and the variation in size is due to the distribution of the position.

\section{Corms Quality: Glucomannan and Calcium Oxa- late (CaOx) Content}

Corms quality both glucomannan or calcium oxalate content of corms harvested from plant grown from middle and edge bulbils were not significantly different. The average of glucomannan content was 48.63 and $37.78 \%$ DW corms harvested from plant grown from middle and 
edge bulbil, respectively (Fig. 4B). In this study it is assumed that corms were not harvested at mature physiological age. Consequently, the content of glucomannan produced by the two plants derived from middle and edge bulbil was not significantly different. Glucomannan content was higher in mature corms than in young corms. Glucomannan within the developing corm changes throughout the growing season and was highest just before the foliage died off, prior to dormancy [27]. Generally foliage died off 5-6 months after planting [3].

Calcium oxalate crystals were also obtained from corms of $A$. muelleri plants derived from bulbils. However there was no significant difference between two plant types in terms of its content. It is suspected that during corms development the formation of calcium oxalate crystals has not been maximized. There is an indirect relationship between the diameter and the density of calcium oxalate in the corms [28].

\section{CONCLUSION}

From this result it can be concluded that the position effect of $A$. muelleri's bulbils on the maternal leaf branch will influence the growth response. The content of glucomannan and $\mathrm{CaOx}$ have no significant difference in young corms.

\section{ACKNOWLEDGEMENT}

The financial support of this work was provided by DPP-SPP Grant Faculty of Mathematics and Natural Sciences, University of Brawijaya.

\section{REFERENCES}

[1] Jansen, P.C.M., C. van der Wilk, W.L.A. Hetterscheid. 1996. Amorphophallus Blume ex Decaisne. In: Flach, M., F. Rumawas (Eds). PROSEA: Plant Resources of SouthEast Asia No. 9. Plant Yielding Non-seed Carbohydrates. Backhuys Publishers, Leiden.

[2] Santoso, E., N. Sugiyama, S. Hikosaka, T. Takano. 2004. Classification of Amorphophallus variabilis in West Java, Indonesia based on morphological characteristics of inflorescences. Jpn J. Trop. Agric. 48(1). 2534.

[3] Sumarwoto. 2005. Iles-iles (Amorphophallus muelleri Blume); Deskripsi dan sifat-sifat lainnya. Biodiversitas. 6. 185-190.

[4] Hetterscheid, W.L.A., S. Ittenbach. 1996. Everything you always wanted to know about Amorphophallus but were afraid to stick your nose into. Aroideana. 19. 7-131.
[5] Yuzammi, Y. 2009. The genus of Amorphophallus Blume ex Decaisne (AraceaeThomsonieae) in Java. Reinwardtia. 13. 112.

[6] McPherson, S., W. Hetterscheid. 2011. Amorphopallus in the wild and in cultivation. The Plantsman. 10. 91-97.

[7] Serafinah, I. 2011. Pola pertumbuhan Porang (Amorphophallus muelleri Blume) dan pengaruh lingkungan terhadap kandungan oksalat dan glukomanan umbi. PhD Thesis. Airlangga University, Surabaya.

[8] Giles, B.E. 1990. The effects of variation in seed size on growth and reproduction in the wild barley Hordeum vulgare ssp. Spontaneum. Heredity. 64. 239-250.

[9] Bregtanolle, F., J.D. Thompson, R. Lumaret. 1995. The influence of seed size variation on seed germination and seedling vigor in diploid and tetraploid Dactylis glomerata L. Ann. Bot. 76(6). 607-615.

[10] Halpern, S.L. 2005. Sources and consequences of seed size variation in Lupinus perennis (Fabaceae): adaptive and nonadaptive hypotheses. Am. J. Bot. 92(2). 205213.

[11] Sumarwoto. 2004. Pengaruh pemberian kapur dan ukuran bulbil terhadap pertumbuhan iles-iles (Amorphophallus muelleri Blume) pada tanah ber-Al tinggi. Ilmu Pertanian. 11. 45-53.

[12] Sumarwoto, Maryana, 2011. Pertumbuhan bulbil iles-iles (Amorphophallus muelleri Blume) berbagai ukuran pada beberapa jenis media tanam. Jurnal IImu Kehutanan. 5. 91-98.

[13] Susko, D.J., L. Lovett-Doust. 2000. Patterns of seed mass variation and their effects on seedling traits in Alliaria petiolata (Brassicaceae). Am. J. Bot. 87. 56-66.

[14] Pellegrino, G., F. Bellusci, A. Musacchio. 2010. The effects of inflorescence size and flower position on female reproductive success in three deceptive orchids. Bot. Stud. 51. 351-356.

[15] Moussavi Nik, M., M. Babaeian, A. Tavassoli. 2012. Effects of seed position on the parental plant on seed weight and nutrient content of wheat (Triticum aestivum) grain in different genotypes. Ann. Biol. Res. 3. 534-542.

[16] Gutterman, Y. 2000. Maternal effects on seeds during development. In: Fenner, M. (Ed). Seeds: The Ecology of Regeneration in Plant Communities. CABI, Wallingford. 
[17] Moravcova, L., I. Perglová, P. Pysĕk, V. Jitĕch, J. PergJ. 2005. Effects of fruit position on fruit mass and seed germination in the alien species Heracleum mantegazzianum (Apiaceae) and the implications for its invasion. Acta Oecol. 28. 1-10.

[18] Wang, A.B., D.Y. Tan, C.C. Baskin, J.M. Baskin. 2010. Effect of seed position in spikelet on life history of Eremopyrum distans (Poaceae) from the cold desert of north-west China. Ann. Bot. 106(1). 95-105.

[19] Arslan, N., A. Ipek, A. Rahimi, G. Ipke. 2013. The effects of placement position and corm size of saffron (Crocus sativus L.) on stigma and corm yields in Ankara conditions. J. Herbal Drug. 4(1). 1-6.

[20] Waithaka, K. 1984. Growth and flowering patterns of Liatris corms in Kenya. Acta Hort. 158. 249-253.

[21] Widjanarko, S.B., A. Faridah, A. Sutrisno. 2014. Optimation of ultrasound-assisted extraction of Konjac flour from Amorphophallus muelleri Blume. In: Williams, P.A., G.O. Phillips (Eds). Gums and The Stabilizer for The Food Industry 17: The Changing Face of Food Manufacture: The Role of Hydrocolloids. Royal Society Chemistry, Cambridge.

[22] Tartirat, O., S. Charoenrein. 2011. Physicochemical properties of Konjac Glucomannan extracted from Konjac Flour by a simple centrifugation process. Food Sci. Technol. 44. 2059-2063.

[23] Imouha, C.I., F.A. Kalu. 1995 Calcium oxalate dan physico-chemical properties of cocoyam (Colocasia esculenta and Xanthosoma sagittifolium) tuber flour as affected by processing. Food Chem. 54. 6166.

[24] Addai, I.K., P. Scott. 2011. Influence of bulb size at planting on growth and development of the common hyacinth and the lily. Agric. Biol. J. N. Am. 2(2). 298-314.

[25] Memon, N.N., M. Qasim, M.J. Jaskani. 2009. Effect of various corm sizes on the vegetative, floral and corm yield attributes of Gladiolus. Pak. J. Agr. Sci. 46(1. )13-19.

[26] Kareem, A., M.A. Khan, S.U.R. Rehman, I. Afzal. 2013. Different corm sizes affect performance of Gladiolus grandiflorus cvs. Red Majesty and Early Yellow. Adv. Zoo Bot. 1(4). 86-91.

[27] Aroids, B.D. 2000. Plants of the Arum Family. Portland, Oregon: Timber Press.
[28] Indriyani, S., E. Arisoesilaningsih, T. Wardiyati, H. Purnobasuki 2011. A model of relationship between climate and soil factors related to oxalate content in porang (Amorphophallus muelleri Blume) corm. Biodiversitas. 12(1). 45-51. 